\title{
PENGARUH LIKUIDITAS MODAL KERJA TERHADAP PROFITABILITAS PERUSAHAAN SEKTOR PERUNGGASAN YANG TERDAFTAR DI BURSA EFEK INDONESIA
}

\author{
Cosmas A.I. Wardojo ${ }^{* 1}$, Lukytawati Anggraeni**), dan Hendro Sasongko**) \\ *) PT Charoen Pokphand Indonesia Tbk \\ Jl. Ancol VIII/1, Jakarta 14430 \\ **) Departemen Ilmu Ekonomi, Fakultas Ekonomi dan Manajemen, Institut Pertanian Bogor \\ Gedung FEM Lantai 2 Jl. Kamper, Kampus IPB Darmaga Bogor 16680 \\ $\left.{ }^{* * *}\right)$ Fakultas Ekonomi Universitas Pakuan \\ Jl. Pakuan PO Box 452, Bogor 16143
}

\begin{abstract}
Working capital management is one of the most frequently discussed topics in researches, for companies attempt to obtain liquidity and operational efficiency in managing their working capital. Hence, this study aimed to analyze the company profitability and capital policy influences performed by the poultry sector company towards company profitability in the same period. The method in the study was a panel regression by adopting Ordinary Least Square estimation method and by using fixed effects in reference to Chow test results. Classic assumption test and Goodness of Fit Tests were also conducted to examine the selected models. The results showed that the components of cash conversion cycle and net trade cycle have significant positive effects on profitability, enabling the industry to increase profits by effectively managing each part of net working capital.
\end{abstract}

Keywords: cash conversion cycle, net working capital, net trade cycle, profitability, working capital management, ordinary least square

\begin{abstract}
ABSTRAK
Manajemen modal kerja merupakan topik yang paling sering didiskusikan dalam penelitian, perusahaan berusaha mendapatkan likuiditas dan efisiensi operasional dalam mengelola modal kerja mereka. Penelitian ini bertujuan menganalisis profitabilitas perusahaan dan pengaruh kebijakan modal kerja yang dilakukan oleh perusahaan disektor perunggasan terhadap profitabilitas perusahaan dalam kurun waktu yang sama. Metode yang digunakan adalah regresi panel dengan metode pendugaan Ordinary Least Square menggunakan efek tetap berdasarkan hasil uji Chow. Uji asumsi klasik dan Goodness of Fit Uji juga telah dilakukan untuk menguji model yang terpilih. Hasil penelitian menunjukkan bahwa konversi kas komponen siklus dan siklus perdagangan bersih berpengaruh positif signifikan terhadap profitabilitas, sehingga industri dapat meningkatkan keuntungan dengan mengelola secara efektif setiap bagian dari modal kerja bersih.
\end{abstract}

Kata kunci: siklus konversi kas, modal kerja bersih, net trade cycle, profitabilitas, pengelolaan modal kerja, ordinary least square.

\footnotetext{
${ }^{1}$ Alamat Korespondensi:

Email: dwardojo@gmail.com
} 


\section{PENDAHULUAN}

Konsumsi daging unggas telah mengalami peningkatan sangat dramatis dan tersebar luas, sementara perubahan permintaan akan konsumsi daging sapi, babi, dan produk susu bervariasi antar negara dan adanya perbedaan budaya. Permintaan konsumsi daging di masa mendatang diperkirakan tumbuh dengan tingkat pertumbuhan yang kurang lebih sama dibanyak Negara berkembang, Sementara itu peningkatan pertumbuhan permintaan di Cina akan meningkat tajam dan menyebabkan terjadinya impor besar-besaran di Cina (Andrew et al. 2008).

Indonesia dengan jumlah penduduk 220 juta tentu saja merupakan pasar yang besar. Oleh karena itu, tidak mengherankan bahwa negara-negara besar yang memproduksi broiler (seperti Amerika Serikat dan Brazil) menjadikan Indonesia sebagai target pasar yang baik. Hingga tahun 2008, Indonesia telah mengimpor sekitar 217.056 juta broiler (Prayugo et al. 2012)

Pelaku usaha industri perunggasan di Indonesia tergabung dalam Forum Masyarakat Perunggasan Indonesia (FMPI), FMPI terdiri dari beberapa organisasi yang menjadi bagian dari industri perunggasan, antara lain: GPPU (Gabungan Perusahaan Pembibitan Unggas) dan GPMT (Gabungan Perusahaan Makan Ternak). Hanya empat Perusahaan anggota dari asosiasi FMPI yang terdaftar dalam Bursa Efek Indonesia (BEI), keempat perusahaan tersebut memiliki kegiatan usaha baik dalam sektor perunggasan maupun pakan ternak dan juga merupakan anggota asosisasi GPPU maupun GPMT. Perusahaan-perusahaan yang dimaksud adalah 1) PT Charoen Pokphand Indonesia Tbk (CPIN), 2) PT Japfa Comfeed Indonesia Tbk (JPFA), 3) PT Malindo Feedmill Tbk (MAIN), 4) PT Sierad Produce Tbk (SIPD).

Tren kenaikan konsumsi daging ayam yang meningkat dari tahun ketahun tentunya akan mendorong para pelaku di sektor perunggasan untuk meningkatkan produksi dengan melakukan ekspansi usahanya baik perusahaan pembibitan unggas, pakan ternak dan peternak. GPPU mencatat pertumbuhan sebesar 15\% pertahun untuk produksi DOC (anak ayam usia sehari) Broiler dan memperkirakan laju pertumbuhan yang sama ditahun 2014 naik menjadi 2,47 milyar Doc dari 2,15 milyar DOC pada tahun sebelumnya. Sedangkan GPMT memperkirakan pertumbuhan sebesar 11\% dalam 5 tahun terakhir dan diperkirakan akan meningkat menjadi 15,4 Juta ton pada tahun 2014 dibandingkan 13,8 juta ton pada tahun sebelumnya. Pertumbuhan tersebut merupakan jawaban atas tingginya permintaan masyarakat terhadap produksi ayam potong.

Kebijakan pembelanjaan adalah menyangkut pengalokasian dan atau kebijaksanaan investasi dalam berbagai aktiva dan kebijaksanaan pemenuhan dana atau pemilihan sumber dana. Mengingat penting dan strategisnya manajemen modal kerja pada suatu perusahaan dalam rangka kelangsungan hidup, perkembangan, pertumbuhannya yang dihadapkan pada situasi persaingan maka perlu diperhatikan beberapa aspek dari cara pembelanjaan modal kerja, likuiditas, tingkat perputaran modal kerja, kapasitas aktiva lancar yang mempunyai hubungan atau pengaruh secara serentak terhadap ROA (Estiasih dan Pudji, 2005).

Dalam melakukan ekspansi dan untuk meningkatkan produksi, perusahaan melakukan investasi baik jangka pendek atau jangka panjang. Keputusan investasi perusahaan merupakan keputusan finasial yang terpisah dari keputusan operasioal perusahaan, namun keputusan pendanaan investasi akan memengaruhi kebijakan modal kerja perusahaan. Dari Laporan Keuangan Tahunan Perusahaan 2006-2014, dapat dilihat bahwa keempat perusahaan dalam sektor perunggasan di BEI melakukan ekspansi, dengan mengukur variabel yang diantaranya adalah modal kerja bersih, penjualan bersih, Return on Asset (ROA), Return on Equity (ROE), Earning After Tax (EAT), Gross Operating Profit (GOP). Untuk melihat ekspansi yang dilakukan oleh keempat perusahaan tersebut dapat dilihat dari laporan keuangan tahun 2010-2014. Hasil penjelasan didasarkan data yang diperoleh dari Gabungan Perusahaan Pembibitan Unggas (GPPU), konsumsi daging ayam per kilogram per kapita menunjukan peningkatan sejak tahun 2010 hingga tahun 2014 (perkiraan) pada Tabel 1.

Dari laporan keuangan tahunan perusahaan 2010-2014 untuk keempat Perusahaan diatas, dapat dilihat pada Tabel 2, bahwa keempat perusahaan dalam sektor perunggasan di BEI melakukan ekspansi, dari sisi modal kerja, dalam 5 tahun terakhir secara rata-rata total aset lancar meningkat sebesar $25 \%$, total liabilitas jangka pendek sebesar 37\% dan modal kerja meningkat secara rata-rata $81 \%$. Investasi dan pendanaan dari luar perusahaan tentunya akan merubah struktur modal kerja perusahaan, perusahaan perlu menerapkan kebijakan modal kerja yang tepat sebagai salah satu cara untuk mengelola resiko yang timbul agar tetap dapat memiliki 
kemampuan dalam memenuhi liabilitas jangka pendek maupun jangka panjangnya, sebagai bagian dari resiko bisnis untuk mempertahankan profitabilitas dan kesinambungan usaha. Pengukuran variabel kebijakan modal kerja yang diukur oleh Days Inventory on Hand (DIO), Days of Payables outstanding (DPO), Days Sales Outstanding (DSO) dan Net Trade Cycle (NTC). Hal ini dapat digambarkan pada Tabel 2.

Tabel 3 menjelaskan modal kerja untuk mengukur tingkat ekspansi perusahaan perunggasan dapat dihubungkan dengan profitabilitas. Profitabilitas ke 4 perusahaan dalam sektor perunggasan dari penjualan bersih dan laba bersih dapat dilihat pada Tabel 3, bahwa dalam 5 tahun terakhir penjualan bersih ratarata meningkat sebesar $12 \%$. Laba bersih secara umum untuk periode 2010-2012 mengalami rata-rata kenaikan sebesar $4 \%$ per tahun, tetapi mengalami penurunan yang cukup besar pada tahun 2013 dan 2014.

Beberapa penelitian mengemukakan bahwa manajemen modal kerja mungkin memiliki efek penting pada profitabilitas perusahaan (Samiloglu dan Demirgunes, 2008). Hal ini sejalan dengan penelitian dari Shin dan Soenan (1998), Lazaridis dan Tryfonidis (2006), Raheman dan Nasr (2007), yang mengemukan antara lain bahwa modal kerja dapat diukur dari siklus konversi kas yang terdiri dari periode stockholding, koleksi debitur, periode dan periode pembayaran kreditur. Para peneliti ini didukung bahwa investasi yang lebih besar dalam modal kerja mengarah ke penurunan profitabilitas perusahaan (Gracia dan Sanano, 2007; Nazir dan Afza, 2009).

Tabel 1. Konsumsi daging ayam $/ \mathrm{kg} / \mathrm{kapita}$, produksi nasional DOC broiler, konsumsi pakan ternak

\begin{tabular}{cccc}
\hline Tahun & Konsumsi daging ayam/Kg/kapita & $\begin{array}{c}\text { Produksi nasional DOC broiler } \\
\text { (milyar ekor) }\end{array}$ & $\begin{array}{c}\text { Konsumsi pakan ternak } \\
\text { (juta ton) }\end{array}$ \\
\hline 2014 & 9,33 & 2,47 & 15,40 \\
2013 & 9,08 & 2,15 & 13,80 \\
2012 & 6,97 & 1,84 & 12,70 \\
2011 & 6,28 & 1,66 & 11,30 \\
2010 & 4,99 & 1,40 & 9,90 \\
\hline
\end{tabular}

Sumber: GPPU, laporan keuangan perusahaan, diolah kembali tahun 2010-2014

Tabel 2. Aset lancar, liabilitas jangka pendek dan modal kerja bersih perusahaan sektor perunggasan terdafar di BEI 2010-2014 (dalam Milyar Rp)

\begin{tabular}{lrrrrrrrrr}
\hline \multicolumn{1}{c}{$\begin{array}{c}\text { Perusahaan sektor } \\
\text { perunggasan }\end{array}$} & \multicolumn{2}{c}{2014} & \multicolumn{2}{c}{2013} & 2012 & 2011 & 2010 \\
\hline CPIN & & & & & & & & & \\
Total aset lancar & $10.009,7$ & $13 \%$ & $8.824,9$ & $23 \%$ & $7.180,9$ & $37 \%$ & $5.225,8$ & $22 \%$ & $4.274,6$ \\
Total liabilitas jangka pendek & $4.467,2$ & $92 \%$ & $2.327,0$ & $7 \%$ & $2.167,7$ & $60 \%$ & $1.357,9$ & $-7 \%$ & $1.461,3$ \\
Modal kerja & $5.542,4$ & $-15 \%$ & $6.497,9$ & $30 \%$ & $5.013,2$ & $30 \%$ & $3.867,9$ & $37 \%$ & $2.813,3$ \\
JPFA & & & & & & & & & \\
Total aset lancar & $8.709,3$ & $-3 \%$ & $9.004,7$ & $40 \%$ & $6.429,5$ & $30 \%$ & $4.932,3$ & $11 \%$ & $4.435,2$ \\
Total liabilitas jangka pendek & $4.916,4$ & $13 \%$ & $4.361,5$ & $24 \%$ & $3.523,9$ & $14 \%$ & $3.100,0$ & $84 \%$ & $1.686,7$ \\
Modal kerja & $3.792,9$ & $-18 \%$ & $4.643,1$ & $60 \%$ & $2.905,6$ & $59 \%$ & $1.832,3$ & $-33 \%$ & $2.748,5$ \\
MAIN & & & & & & & & & \\
Total aset lancar & $1.875,2$ & $88 \%$ & 997,0 & $11 \%$ & 894,2 & $24 \%$ & 720,5 & $42 \%$ & 507,4 \\
Total liabilitas jangka pendek & $1.742,4$ & $77 \%$ & 986,5 & $16 \%$ & 852,7 & $66 \%$ & 515,0 & $44 \%$ & 356,6 \\
Modal kerja & 132,8 & $1164 \%$ & 10,5 & $-75 \%$ & 41,5 & $-80 \%$ & 205,4 & $36 \%$ & 150,8 \\
SIPD & & & & & & & & & \\
Total aset lancar & $1.720,6$ & $23 \%$ & $1.403,4$ & $-15 \%$ & $1.660,3$ & $35 \%$ & $1.229,33$ & $15 \%$ & $1.066,70$ \\
Total liabilitas jangka pendek & $1.203,3$ & $-2 \%$ & $1.224,8$ & $-15 \%$ & $1.435,7$ & $63 \%$ & 882,6 & $56 \%$ & 564,1 \\
Modal kerja & 517,3 & $190 \%$ & 178,6 & $-20 \%$ & 224,7 & $-35 \%$ & 346,7 & $-31 \%$ & 502,6 \\
\hline
\end{tabular}

Sumber: Laporan Keuangan Perusahaan Tahunan 2010-2014, diolah kembali 
Analisis dengan menggunakan rasio keuangan dapat memudahkan para penganalisis untuk mendapatkan gambaran mengenai kondisi dan kebijakan suatu perusahaan atau dengan kata lain untuk mengetahui apakah suatu perusahaan tersebut dapat menggunakan sumber dananya secara efesien dan efektif mungkin atau tidak. Pengukuran keberhasilan pengelolaan modal kerja dapat menggunakan rasio perputaran modal kerja. Dengan menggunakan rasio ini dapat diketahui efektivitas penggunaan modal kerja perusahaan pada satu periode tertentu, Kasmir (2010). Dengan diketahui nilai kebijakan modal perusahaan maka akan dilakukan analisis kebijakan modal kerja perusahaan di sektor perunggasan. Menurut Charitou et al. (2010) pemanfaatan sumber daya perusahaan secara efisien, berhubungan dengan pengelolaan modal kerja, berarti bahwa manajemen harus menemukan cara yang efektif dan efisien dalam menangani kas yang tersedia untuk operasi sehari-hari agar mencapai hasil yang optimal.

Mengukur perputaran modal kerja adalah membandingkan penjualan bersih perusahaan dengan modal kerjanya selama satu periode, sehingga melalui rasio ini dapat diketahui apabila semakin tinggi perputaran modal kerja maka semakin efektif penggunaan modal kerja perusahaan, sebaliknya semakin rendah perputaran modal kerja semakin tidak efektif penggunaan modal kerja perusahaan sehingga menyebabkan terhambatnya kegiatan operasional perusahaan yang pada akhirnya akan menghambat kemampuan perusahaan dalam perolehan keuntungannya. Hal ini harusnya berlaku juga untuk penelitian yang mencakup perusahaan sektor perunggasan di Indonesia, yaitu analisis kebijakan modal kerja dan profitabilitas perusahaan di sektor perunggasan yang terdaftar pada Bursa Efek Indonesia (BEI) dalam kurun waktu 2006-2014. Dengan demikian, dapat dilihat pengaruh kebijakan modal kerja yang dilakukan oleh perusahaan disektor perunggasan terhadap profitabilitas perusahaan dalam kurun waktu yang sama. Hal inilah yang menjadi latar belakang penelitian, yaitu apakah perusahaan memanfaatkan modal kerjanya dengan baik sehingga bisa menghasilkan keuntungan bagi perusahaan. Oleh karena itu, penelitian ini bertujuan untuk menganalisis profitabilitas perusahaan dan pengaruh kebijakan modal kerja yang dilakukan oleh perusahaan disektor perunggasan terhadap profitabilitas perusahaan dalam kurun waktu yang sama.

\section{METODE PENELITIAN}

Penelitian ini akan menggunakan data sekunder berupa laporan keuangan kwartalan dan tahunan dari empat perusahaan sektor perunggasan dari tahun 2006 sampai dengan tahun 2014 kuartalan yang terdaftar di BEI. Data tersebut diambil dari website IDX dengan alamat http:// idx.co.id. Jenis data yang digunakan dalam penelitian ini adalah data panel yang terdiri atas empat individu, yaitu empat perusahaan dengan data laporan keuangan rentang waktu 2006 sampai 2014 kuartalan. Data yang berhasil dihimpun menunjukkan bahwa masing-masing perusahaan memiliki jumlah observasi yang sama dan merupakan ciri data panel yang seimbang (Gujarati, 2012).

Metode yang digunakan pada penelitian ini adalah purposive sampling. Penggunaan metode sampling dengan purposive sampling karena penelitian ini hanya mengacu pada industri perunggasan di Indonesia dan elaku usaha industri perunggasan di Indonesia tergabung dalam Forum Masyarakat Perunggasan Indonesia (FMPI) hanya empat Perusahaan yang terdaftar dalam BEI. Empat perusahaan yang memiliki kegiatan usaha baik dari hulu ke hilir dalam sektor perunggasan diambil sebagai sampel agara secara bisnis proses sama dan struktur keuangannya sama. Keempat perusahaan tersebut adalah 1) PT Charoen Pokphand Indonesia Tbk (CPIN), 2) PT Japfa Comfeed Indonesia Tbk (JPFA), 3) PT Malindo Feedmill Tbk (MAIN), 4) PT Sierad Produce Tbk (SIPD).

Tabel 3. Penjualan bersih dan laba bersih perusahaan sektor perunggasan terdaftar di BEI 2010-2014

\begin{tabular}{lrrrrrrrrrr}
\hline $\begin{array}{c}\text { Perusahaan } \\
\text { sektor } \\
\text { perunggasan }\end{array}$ & \multicolumn{4}{c}{ Penjualan bersih (Milyar Rp.) } & \multicolumn{6}{c}{ Laba bersih (Milyar Rp.) } \\
\cline { 2 - 11 } & 2014 & 2013 & 2012 & 2011 & 2010 & 2014 & 2013 & 2012 & 2011 & 2010 \\
\hline CPIN & $29.150,3$ & $25.663,0$ & $21.310,9$ & $17.958,0$ & $15.077,8$ & $2.106,9$ & $3.451,3$ & $3.376,5$ & $2.974,6$ & $2.818,2$ \\
JPFA & $24.458,9$ & $21.412,1$ & $17.832,7$ & $15.633,1$ & $13.955,8$ & 542,5 & 895,9 & $1.364,9$ & 872,3 & $1.436,9$ \\
MAIN & $4.502,1$ & $4.193,1$ & $3.349,6$ & $2.634,5$ & $2.036,5$ & $(108,3)$ & 310,9 & 302,4 & 205,0 & 224,9 \\
SIPD & $2.505,6$ & $3.854,3$ & $4.354,5$ & $4.029,1$ & $3.642,5$ & 24,8 & 11,3 & 19,8 & 34,0 & 93,1 \\
\hline \hline
\end{tabular}


Regresi dengan menggunakan data panel disebut model regresi data panel. Ada beberapa keuntungan yang diperoleh dengan menggunakan data panel. Pertama, data panel merupakan gabungan data data time seris dan cross section mampu menyediakan data yang lebih banyak sehingga akan menghasilkan degree of freedom yang lebih besar. Kedua, menggabungkan informasi dari data time series dan cross section. Dapat mengatasi masalah yang timbul ketika ada masalah penghilangan variabel (ommited-variable).

Analisis regresi data panel adalah analisis regresi dengan struktur data yang merupakan data panel. Umumnya pendugaan parameter dalam analisis regresi dengan data cross section dilakukan menggunakan pendugaan metode kuadrat terkecil atau disebut Ordinary Least Square (OLS). Data panel adalah gabungan antara data cross section dan data time series, dimana unit cross section yang sama diukur pada waktu yang berbeda. Maka dengan kata lain, data panel merupakan data dari beberapa individu sama yang diamati dalam kurun waktu tertentu. Jika kita memiliki $\mathrm{T}$ periode waktu $(\mathrm{t}=1,2, \ldots, \mathrm{T})$ dan $\mathrm{N}$ jumlah individu $(\mathrm{i}=1,2, \ldots, \mathrm{N})$, maka dengan data panel kita akan memiliki total unit observasi sebanyak NT. Jika jumlah unit waktu sama untuk setiap individu, maka data disebut balanced panel. Jika sebaliknya, yakni jumlah unit waktu berbeda untuk setiap individu, maka disebut unbalanced panel. Sedangkan jenis data yang lain, yaitu: data time-series dan data cross-section. Pada data time series, satu atau lebih variabel akan diamati pada satu unit observasi dalam kurun waktu tertentu. Sedangkan data crosssection merupakan amatan dari beberapa unit observasi dalam satu titik waktu. Model regresi data panel dalam penelitian ini adalah sebagai berikut :

$\mathrm{ROA}_{\mathrm{it}}=\mathrm{a}_{0}+\mathrm{a}_{1} \mathrm{DIO}_{\mathrm{it}}+\mathrm{a}_{2} \mathrm{DPO}_{\mathrm{it}}+\mathrm{a}_{3} \mathrm{DSO}_{\mathrm{it}}+\mathrm{a}_{4} \mathrm{NTC}_{\mathrm{it}}+$ $\mathrm{a}_{5}$ Dummy $_{1}+\mathrm{a}_{6}$ Dummy $_{2}+\mathrm{e}_{1 \mathrm{it}}$

$\mathrm{ROE}_{\mathrm{it}}=\mathrm{b}_{0}+\mathrm{b}_{1} \mathrm{DIO}_{\mathrm{it}}+\mathrm{b}_{2} \mathrm{DPO}_{\mathrm{it}}+\mathrm{b}_{3} \mathrm{DSO}_{\mathrm{it}}+\mathrm{b}_{4} \mathrm{NTC}_{\mathrm{it}}+$ $\mathrm{b}_{5}$ Dummy $_{1}+\mathrm{b}_{6}$ Dummy $_{2}+\mathrm{e}_{2 \mathrm{it}}$

$\mathrm{EAT}_{\mathrm{it}}=\mathrm{c}_{0}+\mathrm{c}_{1} \mathrm{DIO}_{\mathrm{it}}+\mathrm{c}_{2} \mathrm{DPO}_{\mathrm{it}}+\mathrm{c}_{3} \mathrm{DSO}_{\mathrm{it}}+\mathrm{c}_{4} \mathrm{NTC}_{\mathrm{it}}+$ $\mathrm{c}_{5}$ Dummy $_{1}+\mathrm{c}_{6}$ Dummy $_{2}+\mathrm{e}_{3 \mathrm{it}}$ $\mathrm{GOP}_{\mathrm{it}}=\mathrm{d}_{0}+\mathrm{d}_{1} \mathrm{DIO}_{\mathrm{it}}+\mathrm{d}_{2} \mathrm{DPO}_{\mathrm{it}}+\mathrm{d}_{3} \mathrm{DSO}_{\mathrm{it}}+\mathrm{d}_{4} \mathrm{NTC}_{\mathrm{it}}+$ $\mathrm{d}_{5}$ Dummy $_{1}+\mathrm{d}_{6}$ Dummy $_{2}+\mathrm{e}_{4 \mathrm{it}}$

Definisi variabel dependen yaitu EAT (Laba bersih setelah pajak) dan variabel independen DSO (avg. accounts receivable/sales) x 365, DPO (avg.accounts payable/COGS) x 365, DIO (avg.inventory/COGS) x $365, \mathrm{CCC}$ ( DSO + DIO - DPO), NTC (Net sales/Net working capital)/365, Dummy 1 Dummy krisis global 0 = tidak krisis (tahun 2007 dan 2010-2014 , 1=krisis (tahun 2008-2009, Dummy2 adalah Dummy Harga Unggas $0=$ normal (tahun 2007-2011 dan 2014) $1=$ harga turun (tahun 2012-2013).

ROA dan ROE akan menganalisis kinerja perusahaan menghasilkan keuntungan baik dari sisi aset maupun sisi ekuitas. DPO adalah rata-rata periode hutang sebuah perusahaan, berapa lama perusahaan membayar faktur dari kreditur perdagangan seperti pemasok, semakin lama periode hutang maka semakin banyak uang dalam modal kerja dan arus kas. DIO menunjukkan berapa hari rata-rata perusahaan mampu merubah persediaannya menjadi penjualan, secara umum DIO yang lebih rendah lebih baik. Pada Siklus konversi kas, CCC mengukur lamanya waktu atau hari yang dibutuhkan untuk sumber daya terikat proses produksi dan penjualan sebelum dikonversi menjadi uang tunai melalui penjualan.

Shin dan Soenen (2000) mengatakan bahwa CCC tidak cukup dijadikan satusatunya pembanding kinerja perusahaan, untuk itu Shin dan Soenen menggunakan NTC ( yaitu CCC dibagi dengan penjualan bersih), NTC menghitung jumlah hari penjualan yang harus dibiayai perusahaan, ceteris paribus. NTC yang lebih pendek membuat arus kas bersih meningkat, perusahaan lebih efisien dalam mengelola modal kerja maka keperluan pinjaman dari luar perusahaan menjadi lebih rendah dan kinerja keuangan lebih baik.

Tahapan yang dilakukan dalam penelitian ini pada tahap awal adalah pengumpulan data laporan keuangan empat perusahaan perunggasan di Indonesia dalam kurun waktu 2006 sampai 2014. Setelah dilakukan pengumpulan data, maka dilakukan pemilahan data sesuai dengan variabel-variabel yang dibuthkan untuk penelitian. Langkah berikutnya yaitu perhitungan data variabel dalam penelitian untuk dianalisis lebih lanjut dengan model regresi panel. Analisis regresi panel menghasilkan tiga jenis model yang akan diperbandingkan yaitu model PLS, FEM dan REM. Untuk menetukan model terbaik yang dipakai dalam penelitian maka langkah selankutnya adalah menggunakan uji pemilihan model terbaik dengan uji Chow dan uji Hausman. Setelah diperoleh model terbaik maka dikaitkan dengan teori penelitian dan menjelaskan hasil model untuk implikasi manajerial. 
Data laporan keuangan dari tahun 2006-2014 terjadi dua kali guncangan ekonomi yaitu krisis global 2008 dan turunnya harga ayam tahun 2013-2104. Pada saat terjadi krisis ekonomi, modal kerja dan profitabilitas sektor perunggasan masih menunjukkan tren meningkat, namun pada dua tahun terakhir 2013-2014 saat terjadi penurunan harga ayam, modal kerja tetap menunjukkan peningkatan tetapi profitabilitas memperlihatkan kecenderungan yang menurun. Berdasarkan kerangka pemikiran tersebut, peneliti ini ingin membuktikan pengaruh likuiditas terhadap profitabilitas. Kerangka pemikiran penelitian selengkapnya pada Gambar 1 .

Berdasarkan model persamaan regresi panel yang dibangun, maka hipotesis penelitian ini adalah .

H1 : Manajemen Modal kerja (DIO, DPO, DSO, NTC) berpengaruh significant terhadap Profitabilitas (ROA, ROE, EAT dan GOP )

$\mathrm{H} 2$ : Terdapat pengaruh kejadian krisis dan penurunan harga unggas (Dummy1 dan Dummy 2) terhadap profitabilitas .

\section{HASIL}

\section{Hasil Analisis Modal Kerja}

Perusahaan yang mempunyai kemampuan membayar belum tentu memiliki kemampuan untuk membayar atau belum tentu dapat memenuhi segala kewajiban finansial yang harus segera dipenuhi. Perusahaan baru dapat kemampuan membayar apabila semua kewajiban sudah terpenuhi dengan kekuatan membayarnya sangat besar (Nugraha, 2012).

Tujuan pertama dalam penelitian ini dapat dijelaskan pada Tabel 4 dengan membandingkan rata-rata perusahaan selama kurun waktu 2006-2014 dengan tolok ukur industri. Karena tidak ada tolok ukur industri yang menjadi acuan maka peneliti menggunakan ratarata dari nilai variabel ukuran modal kerja keempat perusahaan perusahaan unggas yang terdaftar di BEI dalam kurun waktu 2006-2014 sebagai tolok ukur industri (Dewayanti, 1996). Rangkuman dari data kinerja keuangan dalam menganalisis kebijakan modal kerja dari keempat perusahaan selengkapnya dapat dilihat pada Tabel 4 .

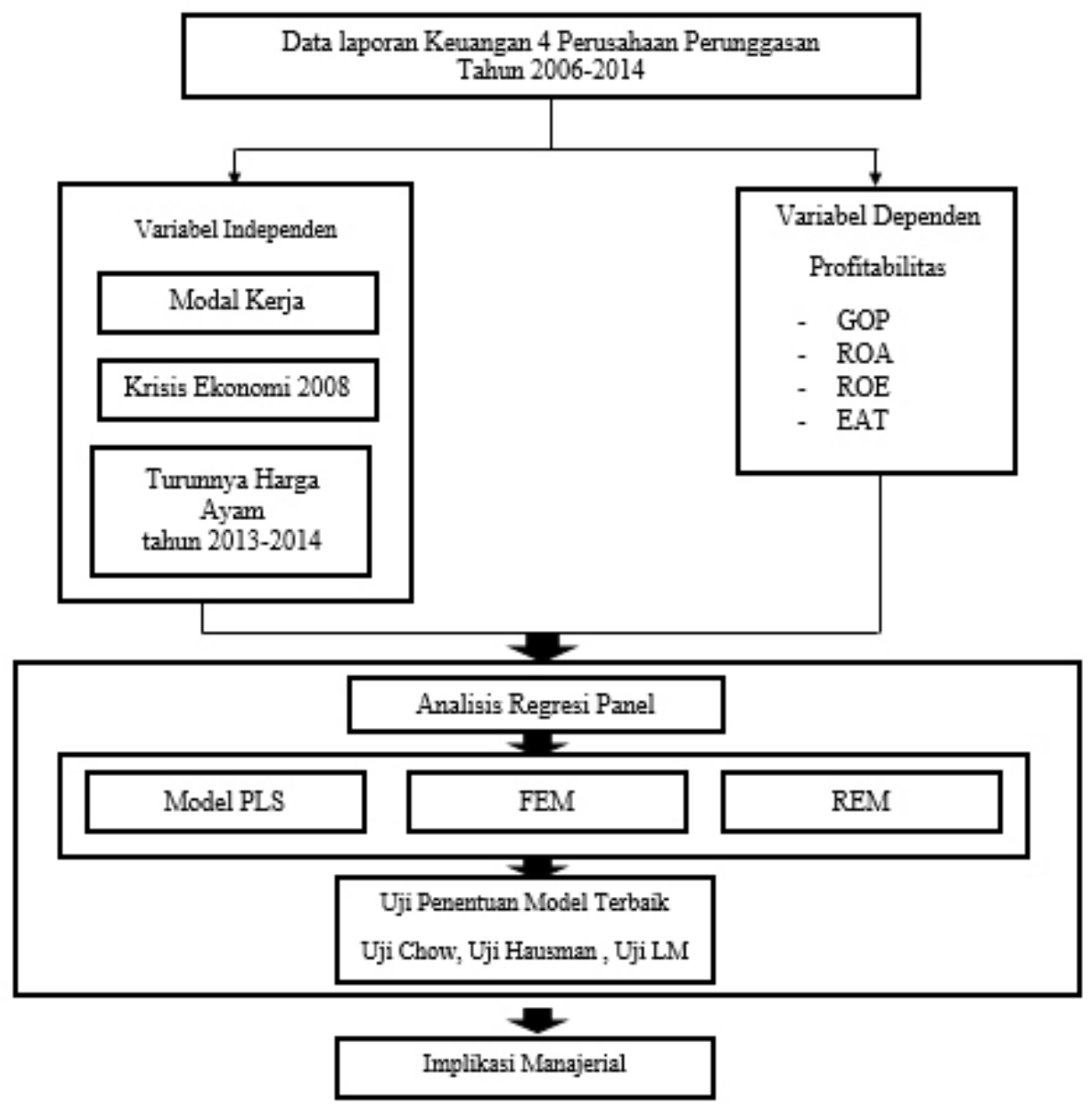

Gambar 1. Kerangka pemikiran penelitian 
Tabel 4. Tolok ukur industri dan variabel ukuran modal kerja perusahaan 2006-2014

\begin{tabular}{lrrrrr}
\hline \multirow{2}{*}{ Perusahaan } & \multicolumn{5}{c}{ Nilai tolok ukur industri } \\
\cline { 2 - 6 } & \multicolumn{1}{c}{ DSO } & DPO & DIO & CCC & NTC \\
\hline CPIN & 53,108 & 39,935 & 88,561 & 101,734 & 0,013 \\
JPFA & 39,316 & 41,455 & 200,689 & 198,550 & 0,010 \\
MAIN & 46,395 & 74,257 & 70,230 & 42,368 & 0,049 \\
SIPD & 104,647 & 28,668 & 79,484 & 155,463 & 0,007 \\
\hline \multicolumn{1}{c}{ Tolok ukur } & 60,867 & 46,079 & 109,741 & 124,529 & 0,020 \\
\hline
\end{tabular}

Sumber: Laporan keuangan perusahaan diolah kembali tahun 2006-2014

Kebijakan modal kerja yang diukur berdasarkan nilai-nilai DSO, DPO, DIO, CCC dan NTC untuk keempat perusahaan dalam industri perunggasan. DSO merupakan ukuran rata-rata jumlah hari yang dibutuhkan perusahaan untuk mengubah piutang menjadi kas. JPFA membutuhkan waktu 39 hari untuk mengubah piutang menjadi kas. Bila dibandingkan dengan tolok ukur industri yang membutuhkan 60 hari, dapat diartikan bahwa JPFA lebih efisien dalam hal pengelolaan waktunya. Sedangkan SPID adalah perusahan yang memerlukan waktu 104 hari, jauh diatas tolok ukur industri. Semakin pendek hari maka semakin baik untuk sebuah perusahaan bisa menjalankan perusahaannya.

DPO dapat bervariasi dari perusahaan ke perusahaan atau industri, tolok ukur industri adalah 46 hari dan bila tiga perusahaan dalam industri seperti CPIN, JPFA, SIPD membayar tagihan lebih cepat dari tolok ukur, maka yang dilakukan untuk meningkatkan arus kas adalah dengan memperhatikan diskon diperoleh atau menghindari kenaikan harga. Tolok ukur industri 109 hari, sedangkan rata-rata JPFA adalah 200 hari artinya kemampuan perusahaan dalam merubah persediaan sangat lambat. Sedangkan bila dibandingkan dengan CPIN , MAIN, dan SIPD, ketiganya yang memiliki nilai rata-rata lebih kecil dari tolok ukur industri sehingga mereka memiliki kemampuan yang lebih baik dibandingkan dengan tolok ukur indurstri. Tolok ukur industri adalah 124 hari, maka MAIN dengan 42 hari merupakan perusahaan yang memiliki CCC paling cepat kemudian diikuti oleh CPIN dengan 101 hari sedangkan yang paling lambat siklus konversi kasnya JPFA selama 198 hari. Tolok ukur Industri untuk NTC 0,020 , rata-rata SIPD merupakan yang paling rendah 0,007 sedangkan MAIN memiliki nilai NTC yang paling tinggi dengan 0,049 .

\section{Hasil Analisis Profitabilitas}

Menjawab tujuan kedua dengan statistika deskriptif untuk data penelitian semua variabel yang disajikan dalam Tabel 5 dan 6 yang menggambarkan rata-rata masing-masing variabel pengukuran dengan tolok ukur industri dari keempat perusahaan dapat dilihat pada Tabel 5 ROA dan ROE akan menganalisis kinerja perusahaan menghasilkan keuntungan baik dari sisi aset maupun sisi ekuitas. CPIN merupakan satusatunya perusahaan yang memiliki nilai ROA jauh diatas tolok ukur dan ROE yang nilainya sama dengan nilai tolok ukur (Tabel 6). Artinya, profitabilitas CPIN dibandingkan dengan ketiga perusahaan lainnya dalam industri dapat dikatakan paling baik.

Rata-rata persen pertumbuhan tiap tahun dari tahun 2006-2014 variabel penjualan bersih, EAT, GOP dan modal kerja bersih (Tabel 6). CPIN memiliki nilai yang sangat baik untuk keempat variabel, MAIN juga memiliki nilai rata-rata EAT tertinggi dan penjualan bersih, nilai pada MAIN sangat bagus, karena terdapat injeksi sumber dana jangka pendek yaitu tahun 2008 dan 2012 sehingga modal kerja naik.

\section{Hasil Analisis Regresi Panel}

Pengolahan dengan menggunakan regresi panel memerlukan tiga pendekatan model diantaranya adalah model PLS, model FEM dan model REM. Tahapan awal dalam hasil pengolahan model dengan regresi panel menghasilkan masing-masing pendekatan, dalam penelitian ini, model REM tidak dapat dianalisis karena keterbatasan individu, yaitu hanya menggunakan empat individu perusahaan. Hasil penelitian ini, menunjukkan dua model yangdapat diuji yaitu model PLS dan model FEM, untuk menguji model yang cocok dan baik dalam menduga pengaruh variabel independen terhadap variabel dependen dilakukan uji chow. Dari tabel 6 menghasilkan uji chow dengan nilai 
$\operatorname{prob}(0,0000)$ lebih kecil dari alpha 5\% maka tolak H0. Artinya, model yang terpilih adalah FEM. Berikut adalah hasil estimasi parameter model regresi dengan model FEM. Berikut adalah hasil uji chow yang dapat dilihat pada tabel 7. Hipotesis uji Chow adalah H0: Model yang terpilih adalah PLS dan H1: Model yang terpilih adalah FEM.

Pengaruh masing-masing variabel independen dapat diinterpretasikan terhadap dependen. Variabel DSO memiliki pengaruh signifikan negatif terhadap ROA, ROE, EAT dan GOP. Menurut hasil penelitian Bambang (2001) menyatakan perputaran piutang menunjukkan periode terikatnya modal kerja dalam piutang dimana semakin cepat periode berputarnya menunjukkan semakin cepat perusahaan mendapatkan keuntungan dari penjualan tersebut, sehingga profitabilitas perusahaan juga ikut meningkat. Sebaliknya, semakin lama periode perputaran piutang menunjukkan penurunan terhadap profitabilitas. Hal ini dikarenakan perusahaan kurang mampu merubah piutang yang dimiliki menjadi kas. Penjelasan ini didiukung oleh penelitian dari Santoso (2013) yang menyatakan perputaran piutang berpengaruh negatif signifikan terhadap profitabilitas (ROA). Bellouma (2011) dan Maija (2012), DSO berpengaruh negatif terkait dengan profitabilitas perusahaan. Temuan ini konsisten dengan prediksi teori perdagangan kredit dan menyiratkan bahwa perusahaan menawarkan kredit perdagangan yang lebih pendek sebagai instrumen untuk meningkatkan profitabilitas.

Menurut Munawir (2007) pengaruh DPO signifikan negatif terhadap ROE dan GOP, utang dagang mempunyai hubungan yang erat dengan pembelian barang dagangan karena perusahaan yang besar pada umumnya pembeliannya dilakukan secara kredit. Semakin tinggi perputaran utang dagang, semakin cepat perusahaan di dalam membayar utang. Hal ini juga dijelaskan oleh pecking order theory yang menyatakan bahwa perusahaan dengan tingkat profitabilitas yang tinggi justru tingkat hutangnya rendah. Perusahaan yang profitabilitasnya tinggi memiliki sumber dana internal yang memadai. Semakin lama hutang dibayar maka profitabilitas perusahaan akan semakin kecil. Ini menunjukkan bahwa perusahaan tidak mampu melunasi hutang yang dimiliki dalam periode yang cepat. Hal ini sejalan dengan penelitian dari Kithi (2008), yang menunjukkan variabel hutang berpengaruh negatif terhadap profitabilitas. Astuti (2005) melakukan penelitian dengan judul Pengaruh Modal Kerja dan perputaran modal kerja terhadap ROE pada Perusahaan makanan dan minuman go public di Bursa Efek Jakarta, hasil penelitian menunjukkan modal kerja dan perputaran modal kerja secara signifikan berpengaruh terhadap ROE.

Tabel 5. Tolok ukur dan rata-rata variabel kinerja keuangan perusahaan 2006-2014

\begin{tabular}{cccccc}
\hline Variabel & Tolok ukur & CPIN & JPFA & MAIN & SIPD \\
\hline ROA & 6,5 & 12,1 & 5,7 & 6,8 & 1,3 \\
ROE & 19,9 & 19,4 & 20,2 & 38,3 & 1,9 \\
\hline
\end{tabular}

Sumber: Laporan keuangan perusahaan diolah kembali tahun 2006-2014

Tabel 6. Rata-rata variabel pertumbuhan perusahaan tiap tahun 2006-2014

\begin{tabular}{lcccc}
\hline \multicolumn{1}{c}{ Variabel } & CPIN & JPFA & MAIN & SIPD \\
\hline Penjualan bersih & $17,2 \%$ & $14,1 \%$ & $23,1 \%$ & $14,2 \%$ \\
EAT & $54,6 \%$ & $23,4 \%$ & $83,8 \%$ & $-16,9 \%$ \\
GOP & $32,4 \%$ & $24,2 \%$ & $19,4 \%$ & $1,7 \%$ \\
Modal kerja bersih & $37,4 \%$ & $20,0 \%$ & $76,2 \%$ & $15,5 \%$ \\
\hline
\end{tabular}

Tabel 7. Hasil uji-Chow

\begin{tabular}{|c|c|c|c|c|}
\hline Effects test & Statistic & d.f. & Prob. & Kesimpulan \\
\hline ROA & 13,254 & $-3,118$ & 0,000 & Model FEM \\
\hline ROE & 35,018 & $-3,118$ & 0,000 & Model FEM \\
\hline EAT & 23,869 & $-3,118$ & 0,000 & Model FEM \\
\hline GOP & 23,272 & $-3,118$ & 0,000 & Model FEM \\
\hline
\end{tabular}


DIO berpengaruh signifikan positif terhadap GOP, hasil ini sesuai dengan pernyataan Raharjaputra (2009) bahwa semakin cepat tingkat perputaran persediaan, kemungkinan semakin besar perusahaan akan memperoleh keuntungan, begitu pula sebaliknya, jika tingkat perputaran persediaannya rendah berarti persediaan menumpuk maka kemungkinan semakin kecil perusahaan dalam memperoleh profitabilitas.

NTC berpengaruh signifikan negatif terhadap ROE. Sesuai dengan penelitian Shin dan Soenen (2000) yang menyatakan semakin kecil NTC maka semakin efisien manajemen modal kerja sehingga akan meningkatkan kinerja keuangan perusahaan, sehingga akan meningkatkan profitabilitas.

Variabel dummy 2 significant dan memiliki koefisien positif pengaruhnya terhadap EAT dan GOP artinya rata-rata nilai EAT dan GOP pada saat penurunan harga ayam lebih besar dari rata-rata pada saat harga ayam normal, hal ini sejalan dengan penelitian Kariyasa et al. (2003). Hasil analsisis regresi panel pada Tabel 8.

Setelah diperoleh hasil pendugaan parameter dengan regresi panel dan interpretasi pengaruh masing-masing variabel independen terhadap dependen, langkah selanjutnya adalah pengujian asumsi klasik. Dari hasil uji asumsi klasik untuk semua model sudah terpenuhi uji asumsi homoskedastisitas, terbebas dari autokorelasi dan tidak terjadi multikolinieritas.
Penelitian ini menunjukkan bahwa kebijakan modal kerja perusahaan disektor perunggasan yaitu variabel modal kerja DIO, DPO, DSO, NTC dapat digunakan oleh manajemen perusahaan dan investor untuk mengingkatkan kinerja dan melihat kondisi likuiditas dan profitabilitas perusahaan. Dari keempat variabel modal kerja yang berpengaruh signficant terhadap keempat variabel profitabilitas adalah DSO dan memiliki koefisien negatif artinya perputaran piutang menunjukkan periode terikatnya modal kerja dalam piutang dimana semakin cepat periode berputarnya menunjukkan semakin cepat perusahaan mendapatkan keuntungan dari penjualan sehingga langsung dapat meningkatkan profitabilitas.

\section{Implikasi Manajerial}

Bagi manajemen keuangan perusahaan harus memperhatikan nilai DSO dan dipercepat perputarannya sehingga mampu meningkatkan profitabilitas yang lebih tinggi. Dari hasil analisis regresi terbukti untuk industri unggas ada pengaruh CCC terhadap profitabilitas, CCC yang stabil atau menurun adalah pertanda bagus bagi perusahaan, sebaliknya rasio CCC yang naik bukan berarti buruk seharusnya menarik minat analis/investor untuk menganalisis lebih dalam apa penyebab naiknya angka CCC tersebut. Namun, analisis CCC tidaklah cukup harus memperhatikan rasio juga NTC, karena semakin kecil nilai NTC semakin baik kinerja keuangan perusahaan sehingga akan meningkatkan profitabilitas. Kebijakan WCM optimal diharapkan dapat memberikan kontribusi positif terhadap penciptaan nilai perusahaan dan peningkatan profitabilitas (Bilal, 2011).

Tabel 8. Hasil analisis regresi panel

\begin{tabular}{lcrrrrrrr}
\hline \multirow{2}{*}{ Variable } & \multicolumn{2}{c}{ ROA } & \multicolumn{2}{c}{ ROE } & \multicolumn{2}{c}{ EAT } & \multicolumn{2}{c}{ GOP } \\
\cline { 2 - 9 } & Coefficient & Prob. & Coefficient & Prob. & Coefficient & Prob. & Coefficient & Prob. \\
\hline DIO & 0,019 & 0,775 & 0,036 & 0,461 & 0,005 & 0,620 & $0,027^{* *}$ & 0,016 \\
DPO & $-0,023$ & 0,637 & $-0,052^{*}$ & 0,097 & $-0,008$ & 0,202 & $-0,019^{* *}$ & 0,040 \\
DSO & $-0,206^{* *}$ & 0,001 & $-0,220^{* *}$ & 0,000 & $-0,031^{* *}$ & 0,001 & $-0,013^{*}$ & 0,089 \\
NTC & 6,134 & 0,224 & $-7,678^{* *}$ & 0,006 & 0,571 & 0,453 & 0,307 & 0,678 \\
Dummy 1 & $-1,787$ & 0,477 & $-0,129$ & 0,943 & $-0,538$ & 0,209 & $-0,381$ & 0,161 \\
Dummy 2 & 0,522 & 0,676 & $-1,522$ & 0,240 & $0,341^{*}$ & 0,095 & $0,718^{* *}$ & 0,001 \\
C & $139,463^{* *}$ & 0,000 & $155,183^{* *}$ & 0,000 & $21,551^{* *}$ & 0,000 & $12,545^{* *}$ & 0,002 \\
\hline R-squared & 0,5334 & 0,7742 & 0,4894 & 0,4859 \\
\hline R-squared adj & 0,4979 & 0,7570 & 0,4504 & 0,4467 \\
\hline F-Statistic & $14,9907^{* *}$ & $44,9480^{* *}$ & $12,5651^{* *}$ & $12,3943^{* *}$ \\
\hline Prob (F-Statistic) & 0,0000 & 0,0000 & 0,0000 & 0,0000 \\
\hline Durbin-Watson stat & 1,7450 & 1,8287 & 1,9271 & 2,2593 \\
\hline
\end{tabular}

Keterangan:*Signifikan pada alpha $10 \%, * *$ Signifikan pada alpha $5 \%$, ***Signifikan pada alpha $1 \%$ 
Hasil penelitian ini menjelaskan bahwa untuk mengevaluasi efektivitas perusahaan disektor perunggasan dalam mengelola modal kerjanya adalah dengan memakai pendekatan menimimalkan modal kerja dengan syarat modal kerja itu harus cukup untuk membiayai kegiatan operasi perusahaan. Meminimalkan modal kerja bisa dicapai dengan cara diantaranya mempercepat penagihan piutang penjualan, meningkatkan perputaran persediaan dan mengurangi pembelanjaan dengan kas. Hasil penelitian ini juga dapat memberikan bukti empiris bahwa kebijakan modal kerja berpengaruh signifikan terhadap profitabilitas perusahaan, sehingga modal kerja perlu dikelola dengan benar oleh manajemen perusahaan agar memberikan keuntungan yang maksimal kepada pemilik perusahaan.

\section{KESIMPULAN DAN SARAN}

\section{Kesimpulan}

Hasil penelitian dapat disimpulkan bahwa modal kerja bersih pada perusahaan sektor perunggasan mengalami peningkatan dalam kurun waktu 2006-2014 seiring dengan kenaikan penjualan, dapat disimpulkan bahwa perusahaan menjaga likuiditas dengan mengelola DSO, CCC dan pinjaman jangka pendek. Dari keempat perusahaan industri perunggasan CPIN dan JPFA memiliki nilai kebijakan modal kerja yang lebih baik dibandingkan MAIN dan SIPD.

Kinerja keuangan dan Profitabilitas perusahaan disektor perunggasan sangat dipengaruhi oleh DSO dan NTC, secara empiris dapat dilihat pada kinerja perusahaan yang rata-rata nilai DSO dan NTC memiliki gap yang kecil dengan tolok ukur industri. Dari keempat perusahaan di sector perunggasan, CPIN merupakan satu-satunya perusahaan yang memiliki nilai ROA jauh diatas tolok ukur dan ROE yang nilainya sama dengan nilai tolok ukur. Artinya, profitabilitas CPIN dibandingkan dengan ketiga perusahaan lainnya dalam industri dapat dikatakan paling baik.

Hasil pemodelan regresi panel dihasilkan pengujian yang memberikan kesimpulan yang signifikan secara statistik bahwa pengelolaan modal kerja memang nyata memengaruhi profitabilitas perusahaan. Dengan melakukan analisis setiap komponen modal kerja (DSO, DIO, DPO dan NTC) secara terpisah, perusahaan dalam industri perunggasan dalam penelitian ini secara substansial dapat meningkatkan profitabilitas dengan mengelola modal kerja mereka secara secara efisien atau seminimal mungkin.

\section{Saran}

Bagi peneliti selanjutnya, diharapkan agar dapat memfokuskan penelitian pada perusahaan sektor industri tertentu untuk dapat membandingkan seberapa besar pengaruh manajemen modal kerja terhadap profitabilitas. Peneliti memberikan saran untuk meperbanyak jumlah individu dalam pemodelan panel, sehingga dapat menghasilkan variasi model yang lebih banyak. Peneliti mengharapkan untuk penelitian berikutnya menghasilkan periode yang lebih panjang sehingga hasil menjadi lebih akurat.

\section{DAFTAR PUSTAKA}

Astuti HA. 2005. Pengaruh modal kerja dan perputaran modal kerja terhadap return on equty (ROE) pada perusahaan makanan dan minuman yang terdaftar pada perusahaan makanan dan minuman yang terdapat di Bursa Efek Jakarta (BEJ) tahun 2000-2003. [tesis]. Semarang: Universitas Negeri Semarang

Andrew D, Jonathan K, Colin P. 2008. Village Chickens In Household And National Economies. World Development Report.

Bambang R. 2001. Dasar-Dasar Pembelanjaan Perusahaan. Ed ke-7. Yogyakarta: BPFE Yogyakarta.

Bellouma M. 2011, The impact of working capital management on profitability: the case of small and medium-sized export companies in Tunisia. Management International/Gestión Internacional 15(3): 71-88.

Bilal AR, Naveed M, Taliv AN. 2011. Impact of working capital of profitability of cement sector of Pakistan. Interdisciplinary Journal of Contemporary Research in Business 3(7):182191.

Nugraha SB. 2012. Analisis pengaruh efisiensi modal kerja, likuiditas dan solvabilitas terhadap profitabilitas. Jurnal Ilmu Adminnistrasi Bisnis 1(1): 1-11.

Charitou MS, Maria E, Petros L. 2010. The effect of working capital management on firms profitability: Empirical evidence from an emerging market. Journal of Business \& 
Economics Research 8(12): 677-680.

Dewayanti LI. 1996. Tolok ukur kebaruan dalam desain industri. Jurnal Hukum 1(14): 83-96.

Estiasih, Pudji S. 2005. Pengaruh kebijaksanaan modal kerja terhadap ROA perusahaan textile yang go public di BES. Jurnal Keuangan dan Perbankan 9(2): 179-185.

Gracia TP, Sonano PM. 2007. Effects of working capital management on SME profitability. International Journal of Management Finance 3: 164-177.

Gujarati DN. 2012. Dasar-dasar Ekonometrika. Terjemahan Mangunsong RC. Ed ke-2. Jakarta: Salemba Empat.

Kasmir. 2010. Pengantar Manajemen Keuangan. Jakarta: Kencana Prenada Media Group.

Kithi JN. 2008. The Relationship between working capital management and profitability of listed companies in the nairobi stock exchange [tesis]. Kenya: University of Nairobi.

Kariyasa K, Sinaga BM, Adnyana MO. 2003. Proyeksi produksi dan permintaan jagung, pakan, dan daging ayam ras di Indonesia. Socio-Economic of Agriculturre and Agribusiness Journal 4(2): $1-21$.

Maija V. 2012. Optimizing working capital management from processes perspective. Saimaa University of Applied Sciences. Business Administration Lappeenranta. Master's Degree in Business
Administration [tesis]. Finlandia: International Business Management.

Munawir S. 2004. Analisis Laporan Keuangan. Ed ke-4. Yogyakarta: Liberty.

Nazir M, Afra T. 2009. Impact of aggressive working capital management policy on firm's profitability. The UIP Journal of Applied Finance 15: 112115.

Prayugo S, Arief D, Setiadi D. 2012 . Value chain Aaalysis of broiler to increase competitiveness. Jurnal Manajemen and Agribisnis. 9(1): 177181.

Raharjaputra, Hendra. 2009. Manajemen Keuangan dan Akuntansi. Jakarta: Salemba Empat.

Raheman A, Nasr M. 2007. Working capital management and profitability case of Pakistan Firm. International Journal 3: 279-300.

Samiloglu F, Demirgunes K. 2008. The effect of working capital management on firm profitability: Evidence from Turkey. International Journal of Applied Economics and Finance 2(1): 44-50.

Santoso, Clairene. 2013. "Perputaran modal kerja dan perputaran piutang pengaruhnya terhadap profitabilitas pada PT. Pegadaian (PERSERO)". Jurnal EMBA 1(4):1581-1590.

Shin H, Soenen LA. 2000. Liquidity management or profitability - Is there room for both. AFP Exchange 3(1): 87-95. 